\title{
Suggestions on the Unified Construction of Forensic Appraisal System in China
}

\author{
Qiong Zhang \\ Hunan Judicial Police Vocational College \\ Changsha, China
}

\begin{abstract}
Forensic appraisal is an important part of judicial aid system. However, currently there is no relevant unified system and norm in the whole country. In the process of judicial practice, the vulnerable groups are unable to provide evidences due to the fact that they are unable to afford the expenses of forensic appraisal, which eventually leads to the indefinite extension of judicial procedure. Cases that the legal rights and interests of the litigants can not be protected still occurs, which deviates from the purpose of the judicial assistance system and urgently needs to be reformed and improved.
\end{abstract}

Keywords—forensic appraisal; unified structure; suggestions

\section{INTRODUCTION}

Forensic appraisal is referred to an activity, which offers the qualified litigants authentication aid services provided by the forensic appraisal institutions with scientific and expertise knowledge at a reduced cost. Our country is on the way to improve the judicial aid system. As a Forensic Appraisal activity to guarantee the litigant's right of prosecution and the right of proof under economic difficulties, should be an important part of the judicial aid system. But at the moment there is no unified system and norm, and is nslow in establishing forensic appraisal system, which has become a show stopper in the process of law in our country. Constructing a forensic appraisal system in line with our national conditions needs to be improved urgently.

\section{CURRENT SITUATION OF FORENSIC APPRAISAL SYSTEM IN CHINA}

\section{A. The Emerging Background of Forensic Appraisal System in China}

Forensic appraisal is an expertise aid service offered to qualified litigants with a reduced fee, and it's an important part of judicial aid system. Forensic appraisal practice mainly started in 2005 and it's still at full speed till today due to its deep systematic background and complicated social cause., "Decisions on the management of Forensic Appraisal problem" (also named "Decisions" issued on the 28th of February 2005 and implemented on the 1st of October by The National People's Congress of the People's Republic of China brought the re-positioning and function shift of forensic appraisal institutions: firstly, the court revoked the authentication institutions, while due to the change and compression of the scope of the accepted cases, authentication institutions established by the investigation bodies will no longer accept the authentication entrust of litigants. Secondly, "Decisions" boosted the emerging of social authentication institutions, with a result of making the majorities of independent social appraisal organizations participate the market competitions. However, the fees charged by social appraisal organizations have increased dramatically with so many items on the other hand, lose sense of social responsibilities on the public welfare.

\section{B. Values of Forensic Appraisal System in China}

Forensic appraisal is favorable to protect human rights, guarantee the justice and build harmonious society: "Peopleoriented" is about respecting, caring people and taking people's interests and needs as the top priority in order to realize "The well-round and free development of each individual". Based on this, the government of modern legal country setting up assistance system aims to offer legal support to the poor communities free of charge and make sure they can realize their legal rights equally. Following the "Insist justice starting from people" policy, forensic appraisal adheres to people-oriented service as the fundamental aim, and actively carries out Forensic Appraisal, which has effectively safeguarded the legitimate rights and interests of the majority, as well as facilitates building a harmonious society and eliminating unstable factors.

Forensic appraisal is conductive for realizing procedural justice: judicial justice includes substantive justice and procedural justice. Substantive justice is represented and guaranteed by procedural justice. It functions as: admit the different interests of both parties, offer both parties opportunities to fully demonstrate their contradictions and present their opinions, and the referee will make a judgment based on listening and neutrality. Substantive justice depends on the procedural confrontations between both parties. It is impossible for both parties to confront each other equally if there is an unbalance between the strong and weak in their abilities to obtain evidences, as a result, it fails to represent the concept of procedural justice. The concept of procedural justice also reflects the concept of procedural openness, which is the basic feature of democratic society. It can not only guarantee the participation of stakeholders in the process, but also attract the supervision mechanism to prevent the abuse of power. Procedural openness is not only an open authentication conclusion but an open procedure as 
well. The recipients are involved in the activities of forensic appraisal, which has increased the acceptance of authentication conclusion and protected the rights during the procedure.

\section{THE CURRENT SituATION AND DEFICIENCIES OF FORENSIC APPRAISAL}

At present, in China there is no standard system for forensic appraisal. To guarantee the weak and difficult parties to obtain the rights of forensic appraisal service equally, the justice departments from all places are actively discovering, practising, and have carried out various kinds of activities:

- Put the forensic appraisal into the scope of lega laid through local legislation, and the costs of forensic appraisal cases is covered by the fund of lega laid. For example, forensic appraisal is written as one of the lega laid forms in the legislations of Guizhou and Sichuan provinces.

- Write forensic appraisal into the standard documents a the costs of Forensic Appraisal cases is covered by the fund of lega laid, such as Zhejiang, Yunnan etc.

- Through standard documents, advocate forensic appraisal institutions to implement social responsibilities under conditions, and reduce forensic appraisal fees for citizens with economic difficulties, like Liaoning and Ningxia.

- Those who haven't set up the standard of forensic appraisal working system, whether to carry out forensic appraisal activities will be decided by the authentication institutions, for example: Guangdong, Hebei, Hunan etc.

- Establish forensic appraisal through local legislations, and the costs of judicial authetication assistance cases will be guaranteed by the special funds of finance, such as Qinghai.

Through local legislation and standard documents, forensic appraisal is included into the scope of legal aids, which has guaranteed the fund of forensic appraisal but the problem is the scope of authentication assistance is way too limited, which has resulted in a large number of authentication matters involved in non-litigation activities cannot be assisted. Social responsibilities carried by forensic appraisal institutions with conditions via standard documents, or whether to offer forensic appraisal purely decided by authentication institutions themselves, forensic appraisal institutions will take the level of business income and social responsibilities as consideration before making a decision. Authentication aid activities have lots of uncertainties, which is very hard to satisfy the need of the poor people on the matter of authentication assistance, neither is favorable for the judicial justice and harmony of society.

\section{SUGGESTIONS ON THE UNIFIED CONSTRUCTION OF FORENSIC APPRAISAL SYSTEM IN CHINA}

Setting up the unified system of forensic appraisal nation wide can faciliate the working process of forensic appraisal by following certain rules and standard operational procedures; At the same time, through the setup of special financial fund, guarantee the case allowances of forensic appraisal institutions and authentication experts' assistance, so as to urge the implementation of forensic appraisal system to be long lasting. Meanwhile, forensic appraisal activities audited and supervised by the administration of forensic expertise, reduces the procedures of auditing and straightens out the management relationship, which makes it easier to strengthen the supervision and evaluation of authentication assistance work and ensures the forensic expertise assistance to be carried out within standard and in order. In order to improve the system of forensic appraisal, it is necessary to clarify the four problems, which are the responsible body, the target of assistance, the type of assistance, and the management in supervision.

\section{A. Responsible Body of Forensic Appraisal Assistance}

1) The management body of forensic appraisal should be judicial administrative organizations, mainly legal aid institutions: The main responsibilities of the management body have 2 parts: one is to audit the forensic appraisal based on the application of litigants; the other is to send the assigned authentication institutions to proceed the expertise aid. Under the background of national unified legislation, it's more feasible for the legal aid institutions of judicial administrative organizations to audit and investigate altogether. The appointment of social authentication institutions who undertake the obligation of authentication assistance should be mainly made by legal aid institutions directly.

2) The main carrier of forensic appraisal should be social appraisal institutions: Forensic appraisal work has knowledge professionalism and refined techniques such characteristics, which makes it irreplaceable for other staff and institutions. Social authentication institutions are all selfsustainable and have obvious market tendency. Social authentication institutions are not charity organizations and limited to judicial assistance. Therefore, the country should provide appropriate compensations for social appraisal institutions regarding the aid responsibilities; meanwhile, annual tasks of forensic appraisal should be reasonably assigned according to the local business categories and scales.

\section{B. The Target of Assistance}

Forensic appraisal system is to provide poor communities guaranteed judicial justice by the country, thus any legislation must define the appropriate line for the target of assistance and balance the needs between the national aid and the poor community. Forensic appraisal aid system unified by the country should further cover the poor and weak communities in order to form a systematic network of legal aid and authentication assistance. My opinions are: the 
following litigants who cannot afford the expenses of forensic appraisal due to economic difficulties indeed are allowed to ask for forensic appraisal:

- Litigants who meet the requirements for applying for legal aid under their jurisdiction;

- Parties authorized to remit litigation costs by the courts at the municipal and district levels under their jurisdiction.

\section{Types of Assistance}

During judicial practice, if it clearly states that "forensic appraisal assistance can only provide specific types of assistance", it would limit the types of judicial expertise assistance excessively, and may not be able to help vulnerable groups in need of expertise assistance. Therefore, in judicial practice, the types of forensic appraisal assistance should be set according to the actual needs of the difficult parties. The types should include: forensic clinic, forensic pathology, forensic psychosis, forensic physical evidence, document identification, trace identification, microidentification, audio-visual data identification, and other categories approved forensic identification projects.

\section{Supervision and Management of Forensic Appraisal Assistance}

Currently, authentication assistance service provided by judicial administrative organizations to authentication institutions and appraisers lack efficient supervision and management. The follow-up procedures of appraisal assistance, such as filing, evaluation and feedback, are not in place. The appraisal departments haven't been able to establish special files of appraisal assistance, and have not examined appraisal assistance as a hard reference in the annual appraisal. The tracking and feedback work for the recipients is also in the exploratory stage. Therefore, the effective development of Forensic Appraisal aid requires the corresponding departments and personnel to guide, supervise and manage the expertise assistance activities of the Forensic Appraisal institutions, so as to avoid delays and irresponsible authentication caused by the lack of external supervision. The specific measures are:

- The managerial organizations of Forensic Appraisal should evaluate the judicial expertise institutions, reward the authentication institutions and appraisers who have gained great achievements, encourage their enthusiasm and inspire them to rescue the vulnerable groups. At the same time, in case of irresponsible and careless authentications made by judicial appraisal institutions and appraisers, the managerial departments may take punishment measures such as criticism notifications, lowering their credit level, and revoking the occupation registration according to their different circumstances.

- Forensic Appraisal associations should be responsible for assisting, supervising and guiding the work of Forensic Appraisal aid. Managing the Forensic Appraisal institutions and appraisers, apart from administrative management, the self-discipline of Forensic Appraisal institution is also very important. Therefore, as self-disciplined organizations, Forensic Appraisal associations should offer guidance, assistance and supervision to Forensic Appraisal institutions who are responsible for Forensic Appraisal aids in order to better motivate them to implement Forensic Appraisal obligations.

\section{CONCLUSION}

Forensic appraisal system as the most important part of social aid system, is playing an ever important role in protecting judicial justice, maintaining the balance between prosecution and defense, and improving litigation efficiency than any other systems. Meanwhile as a "people-oriented" project, forensic appraisal system is also playing an important role in maintaining the stability of society and building a harmonious society etc, which offers opportunities for people who cannot afford the authentication expenses to get authentication aid through the government, and makes people feel truly "Equality in front of the Law" such constitutional principle. With the non-stop development of society and economy, we have enough reasons to believe that one day in the furture we can find a way to smoothly develop the criminal forensic appraisal legal aid system in our country.

\section{REFERENCES}

[1] Jun Zhang: Understanding and Application of Criminal Evidence Rules, Beijing: Law Press, 2010 (in Chinese).

[2] Yuxiong Lin: Strict Proof and Criminal Evidence, Beijing: Law Press, 2008 (in Chinese).

[3] Ruihua Chen: A Theory of Procedural Sanctions, Beijing: China Legal Publishing House, 2010 (in Chinese).

[4] Yuejun Qian: The Spirit and Practice of the German Laws (2nd edition), Beijing: Social Sciences Academic Press, 2014 (in Chinese).

[5] E. Allan Farnsworth: An Introduction to the Legal System of the United States, revised by Steve Sheppard, translated by Mingqian Li, Shanghai: Shanghai People's Publishing House, 2018 (in English).

[6] Zhichun Du: An Introduction to Forensic Appraisal, Beijing: Higher Education Press, 2015 (in Chinese)

[7] Wuguang Jia, Ning Sang, Ziwen Zheng: Reform and Development of Legal Aid System: Selected Articles of National Legal Aid Collection in year 2012-2013, Beijing: China Democratic and Legal Publishing House, 2013 (in Chinese).

[8] Jinxia Guo: Research on the Problems and Solutions in the Application of Expertise Conclusion, Beijing: China University of Political Science and Law Press, 2009 (in Chinese).

[9] Jiahong He: An Introduction to Expert Testimony, Beijing: Pekin University Press, 2010 (in Chinese).

[10] Hanbo Authentication on Science and Technology Institution, Zhejiang Province, Compilation of Legal and Regulatory Documents on Judicial Appraisal, Beijing: Law Press, 2016 (in Chinese).

[11] Zhihui Jia: Research on Hot Topics of Forensic Appraisal, Beijing People's Publishing House, 2009 (in Chinese).

[12] Colin Evans: A Question of Evidence: The most Controversial Forensic Case in History, translated by Xiaoqing Bi, Shanghai: SDX Joint Publishing Company, 2007 (in English).

[13] Zongzhi Long: The Idea, System and Methodology of Evidence Law, Beijing: Law Press, 2008 (in Chinese). 
[14] Ronald.J.Allan, Richard.B.Coon, Eleanor Swift: Evidence Law: Text, Problem and Case (3rd edition), translated by Baosheng Zhang, Beijing: Higher Education Press, 2006 (in English).

[15] Hua Zhang: Research on Several Problems of Forensic Appraisal Practice, Beijing: Intellectual Property Publishing House, 2009 (in Chinese).

[16] Zelin Su: Full Collection of Theses on Judicial Technical Assistance of People's Courts, Beijing: People's Court Publishing House, 2011 (in Chinese).

[17] Xi Jin, Lin Chang: Collection of Theses of the 1st International Symposium on Evidence Law and Forensic Science, Beijing: China University of Political Science and Law Press, 2009 (in Chinese).

[18] John Rawls: A Theory of Justice, translated by Huaihong He, Baogang He, Shenbai Liao, Beijing: Social Sciences Academic Press, 2009 (in English).

[19] Bangda Chen: The Due Process of Forensic Appraisals in Criminal Proceedings, Beijing: Pekin University Press, 2015 (in Chinese). 